\title{
Opinia na temat komunikatu Komisji do Parlamentu Europejskiego, Rady Europejskiej, Rady, Europejskiego Komitetu Ekonomiczno-Społecznego i Komitetu Regionów: Umocnienie praworządności w Unii. Plan działania (COM(2019) 343 final) ${ }^{1}$
}

\begin{abstract}
Zdaniem autora opinii komunikat z lipca 2019 r. zasadniczo nie generuje bezpośrednich skutków społecznych, gospodarczych i finansowych. Dopiero wprowadzanie w życie niektórych rozwiązań może rodzić następstwa społeczne (wizerunkowe i nie tylko) oraz finansowe (wynikające ze zmian ustawowych i organizacyjnych w razie stwierdzenia niezgodności z zasadą praworządności przyjętych lub obowiązujących rozwiązań krajowych przez Trybunał Sprawiedliwości UE). Ponieważ dokument nie jest projektem aktu prawnego, to według autora opinii nie dotyczy go zasada pomocniczości.
\end{abstract}

Słowa kluczowe: prawo, Unia Europejska

Opinion on the Communication from the Commission to the European Parliament, the European Council, the Council, the European Economic and Social Committee and the Committee of the Regions: Strengthening the rule of law in the Union. Action Plan (COM(2019) 343 final): According to the author of the opinion, the communication of July 2019does not, in principle, have direct social, economic or financial implications. Only the implementation of some of its solutions can cause social (related i.a. to image) and financial (resulting from statutory and organisational changes in the event of non-compliance with the rule of law by the Court of Justice of the EU) consequences. Since the document is not a draft legislative act, the author of the opinion believes that the subsidiarity principle does not apply to it.

Keywords: law, European Union

1 Opinia na temat komunikatu Komisji do Parlamentu Europejskiego, Rady Europejskiej, Rady, Europejskiego Komitetu Ekonomiczno-Społecznego i Komitetu Regionów: Umocnienie praworząności w Unii. Plan działania (COM(2019) 343 final) sporządzona 14 października 2019 r. na zlecenie przewodniczącego Komisji do Spraw Unii Europejskiej; BAS-WAL/WAPM 1786/2019. 


\section{Opinia merytoryczna}

\section{Przedmiot dokumentu UE}

\section{- Treść dokumentu UE}

Dnia 17 lipca 2019 r. Komisja Europejska opublikowała komunikat skierowany do Parlamentu Europejskiego, Rady Europejskiej, Rady, Europejskiego Komitetu Ekonomiczno-Społecznego i Komitetu Regionów: Umocnienie praworządności w Unii. Plan działania (COM(2019) 343 final), (dalej: komunikat z lipca 2019 r.). Komunikat ten zawiera propozycję niezbędnych konkretnych działań na rzecz praworządności, jakie w rozumieniu Komisji należy podjąć w perspektywie krótko- i średnioterminowej (nie są to zatem działania długofalowe, strategiczne, lecz raczej bieżące i taktyczne) $)^{2}$.

Komunikat z lipca 2019 r. podzielono na pięć części: 1) wprowadzenie (s. 1-2), 2) praworządność jako wspólna wartość dla Europejczyków (s. 3-4), 3) wspólna odpowiedzialność wszystkich państw członkowskich i instytucji Unii Europejskiej (s. 4-5), 4) działania służące umocnieniu praworządności (s. 5-18), 5) wnioski i dalsze działania (s. 18). Pierwsze trzy części dokumentu mają charakter wprowadzający - ideowy i służą osadzeniu problemu praworządności $\mathrm{w}$ traktatowych ramach prawnych. Komisja wyjaśnia rozumienie praworządności, jej wagę w procesie integracyjnym oraz uzasadnia swoją rolę w tej materii. Z punktu widzenia narzędzi działania, o których wspomina Komisja, podstawowe znaczenie ma część czwarta. Ostatnia część komunikatu lipcowego stanowi zwięzłe podsumowanie dokumentu.

Komisja Europejska w omawianym komunikacie zmierza do wyjaśnienia treści i funkcji praworządności w Unii Europejskiej. Uznaje, że: 1) Praworządność jest ugruntowana zasada ${ }^{3}$, której podstawowe znaczenie jest jasno zdefiniowane $i$ - pomimo różnic tożsamości narodowych oraz systemów i tradycji prawnych, które Unia musi respektować - jednakowe we wszystkich państwach członkowskich; 2) Zgodnie z zasada praworządności wszystkie organy władzy publicznej musza zawsze działać $w$ ramach ograniczeń określonych przez prawo, zgodnie $z$ wartościami, jakimi sa demokracja i prawa podstawowe, oraz pod kontrola niezależnych $i$ bezstronnych sądów. Praworządność ma bezpośredni wpływ na życie każdego obywatela - jest warunkiem niezbędnym równości wobec prawa i obrony praw jed-

2 Komisja przyznaje w komunikacie (s. 3), że w kontekście wcześniejszych debat: Niektórzy uznali za priorytet opracowanie zestawu narzędzi, natomiast inni byli zdania, że do osiagnięcia znaczacego skutku wystarczy już lepsze egzekwowanie istniejacych narzędzi. W nielicznych uwagach kwestionowano unijny wymiar tej kwestii.

3 Jednak ugruntowanie to nie wydaje się pełne, skoro na s. 3 komunikatu Komisja Europejska stwierdza: znaczenie praworządności dla działań UE, jej obywateli i przedsiębiorców nie dla wszystkich jest oczywiste i wymaga dalszego upowszechniania $i$ wyjaśniania. 
nostki, zapobiegania nadużywaniu władzy przez organy publiczne oraz rozliczalności władz. Poszanowanie praworzadności jest również koniecznym warunkiem zaufania obywateli do instytucji publicznych. Bez takiego zaufania społeczeństwa demokratyczne nie moga funkcjonować. Praworzadność obejmuje rozliczalność sposobu stanowienia prawa, sprawiedliwość w jego stosowaniu i sprawność jego działania. Według orzeczeń Trybunału Sprawiedliwości UE i Europejskiego Trybunału Praw Człowieka pojęcie praworządności obejmuje również kwestie instytucjonalne, takie jak niezależność i bezstronność sądownictwa oraz podział władz. W swych niedawnych orzeczeniach Trybunat Sprawiedliwości UE ponownie podkreślit, że praworzadność ma kluczowe znaczenie dla porządku prawnego UE; 3) Projekt europejski opiera się na stałym przestrzeganiu praworządności we wszystkich państwach członkowskich. Jest to konieczny warunek wstępny skutecznego stosowania prawa UE i wzajemnego zaufania między państwami członkowskimi. Ma to również zasadnicze znaczenie dla prawidłowego funkcjonowania Unii Europejskiej jako przestrzeni wolności, bezpieczeństwa i sprawiedliwości oraz jako rynku wewnętrznego, gdzie przepisy sa skutecznie i jednolicie stosowane, a środki budżetowe sa wykorzystywane zgodnie z obowiązującymi przepisami. Podważanie praworządności zagraża zatem prawnej, politycznej i gospodarczej podstawie funkcjonowania UE. Dlatego właśnie wspieranie i propagowanie praworządności jest głównym zadaniem Komisji Europejskiej, która stoi na straży Traktatów. Niedostateczne przestrzeganie praworządności w jednym państwie członkowskim wpływa na pozostałe, a także na cała Unię, a więc UE ma wspólny interes $w$ rozwiązywaniu problemów w zakresie praworządności, gdziekolwiek się pojawiają.

Poszukując podstawy prawnej dla swoich działań, Komisja Europejska powołuje się nie tyle na art. 7 Traktatu o Unii Europejskiej (TUE) i art. 354 Traktatu o funkcjonowaniu Unii Europejskiej (TFUE), które jako jedyne w traktatach odwołują się do procedur ochrony wartości Unii Europejskiej, w tym praworządności, ile na postanowienia dotyczące obowiązku lojalnej współpracy z art. 4 ust. 3 TUE. Podkreśla zarazem wewnętrzny i zewnętrzny wymiar praworządności jako wspólnej wartości generującej wspólną odpowiedzialność państw członkowskich i instytucji unijnych. Komisja rozwinęła również rozważania dotyczące obowiązku państw członkowskich zagwarantowania obywatelom możliwości korzystania zich praw, zwłaszcza poprzez dostęp do wymiaru sprawiedliwości i sprawiedliwego procesu. W związku z tym odwołała się do art. 19 TUE (dotyczącego statusu, organizacji i właściwości Trybunału Sprawiedliwości) oraz art. 267 TFUE (regulującego procedurę prejudycjalną). Komisja podkreśliła, że: fundamentem praworządności jest prawny obowiązek zagwarantowania niezależności sądów ${ }^{4}$. Komisja podkreśli-

4 Komisja, przywołując wyrok prejudycjalny w sprawie Wilson (C-506/04) z 19 września 2006 r., ECLI:EU:C:2006:587, uznała, że Trybunał Sprawiedliwości przyjął w nim, że: pojęcie „niezależności sądów” jest autonomicznym pojęciem prawa UE, co oznacza, że sędziowie muszą być chronieni przed wszelka zewnętrzna ingerencja, która mogłaby 
ła też, że w swoich orzeczeniach Trybunał Sprawiedliwości UE precyzował pojęcie niezależności sądów krajowych i nakładał na państwa członkowskie, w tym Polskę, obowiązki zawieszenia reform krajowych, niezgodnych z tą zasadą (s. 4-5). Dodała też, również odwołując się do orzecznictwa Trybunału Sprawiedliwości UE, co stanowi poniekąd nowy element, że sąd ten obecnie łączy systematyczne problemy w zakresie praworządności z ich wpływem na finanse Unii ${ }^{5}$.

W najobszerniejszym fragmencie komunikatu z lipca 2019 r. Komisja Europejska określiła zasady leżące u podstaw działania Unii w dziedzinie praworządności oraz wskazała działania, jakie należy podjąć w trzech zakresach (określanych jako filary): a) upowszechniania praworządności, b) zapobiegania problemom z praworządnością (co rozumie jako zagadnienie współpracy i wsparcia na rzecz umocnienia praworządności na szczeblu krajowym), c) reagowania na problemy (rozumie to jako egzekwowanie prawa na szczeblu unijnym w razie niepowodzenia w działaniu mechanizmów krajowych).

W odniesieniu do zasad działania Unii Europejskiej Komisja stwierdziła, że wchodzi w grę uznanie, że: a) zarówno UE, jak i inne państwa członkowskie maja uzasadniony interes $w$ należytym funkcjonowaniu praworządności na szczeblu krajowym, b) główna odpowiedzialność za zapewnienie praworządności spoczywa na każdym państwie członkowskim, przy czym w pierwszej kolejności należy zawsze korzystać z krajowych mechanizmów naprawczych, c) UE musi być w tej kwestii obiektywna i traktować jednakowo wszystkie państwa członkowskie, a wszystkie jej instytucje musza wnosić wkład zgodnie z własna rola instytucjonalna, d) celem działania nie może być nałożenie sankcji, lecz znalezienie rozwiązania, które chroni praworządność, przy czym zasadnicze znaczenie maja współpraca $i$ wzajemne wsparcie, aczkolwiek $w$ ostateczności nie można jednak wykluczać skutecznej, proporcjonalnej i odstraszającej interwencji (s. 5).

W odniesieniu do pierwszego filaru praworządności (upowszechnianie) Komisja przyjęła, że chodzi o upowszechnianie wiedzy na temat wymogów i norm prawa UE oraz znaczenia praworządności dla obywateli i przedsiębiorstw, jak również o wzmocnienie pozycji podmiotów zainteresowanych propagowaniem zagadnień z zakresu praworządności. Komisja ma nadzieję, że upowszechnianie praworządności dozna przyspieszenia za prezydencji fińskiej (jesień 2019 r.).

zagrozić niezależności ich osądu (s. 4). Dla ścisłości Trybunał odniósł zdefiniowane przez siebie wcześniej i wykorzystywane na potrzeby procedury prejudycjalnej pojęcie sądu krajowego do wymogu ustanowienia skutecznej ochrony sądowej na mocy dyrektywy 98/5 dotyczącej wykonywania zawodu prawnika w innym państwie członkowskim niż państwo uzyskania kwalifikacji zawodowych. Trybunał wprawdzie nie posłużył się tutaj terminem "pojęcie autonomiczne”, aczkolwiek można przyjąć, że taki był jego zamiar. Zob. pkt 48-53 wyroku.

5 Komisja przywołuje jednak tylko wyroki dotyczące oszustw podatkowych i nadużyć finansowych związanych z wykorzystywaniem funduszy unijnych, co jednak świadczy o specyficznym typie takiego powiązania. 
W działaniach na rzecz upowszechniania praworządności Komisja podkreśla rolę: a) społeczeństwa obywatelskiego, mediów, środowiska akademickiego i systemów edukacyjnych państw członkowskich (w tym zakresie Komisja zobowiązała się do podjęcia koncepcji dorocznego wydarzenia poświęconego praworządności, opartego na dialogu z reprezentacją społeczeństwa obywatelskiego i władz państw członkowskich na szczeblu unijnym i między nimi, a także wzmocnienia finansowania aktywności społeczeństwa obywatelskiego, niezależnych mediów w ramach przyszłych programów „Prawa i wartości” czy „Kreatywna Europa”, wreszcie stymulację finansową przez badania nad praworządnością; Komisja zadeklarowała, że będzie zwracała też większą uwagę na próby wywierania nacisków na społeczeństwo obywatelskie czy niezależne media oraz upowszechniała wyniki badań nad praworządnością); b) przejrzystości i dostępu do informacji (Komisja zapowiedziała m.in. opracowanie specjalnej strategii komunikacyjnej); c) sieci europejskich sądów najwyższych, sądów administracyjnych, szkoleń sędziowskich, sądów konstytucyjnych, rzeczników praw obywatelskich (także europejskich sieci sądownictwa, prokuratorów Rady Europy) w propagowaniu i wymianie koncepcji i najlepszych praktyk; d) parlamentów narodowych (łącznie ze współpracą międzyparlamentarną, także między parlamentem narodowym a Parlamentem Europejskim) w sferach stanowienia prawa i rozliczalności organów władzy wykonawczej; e) Rady Europy (również w kontekście umowy o współpracy z Unią Europejską z 2007 r.; Komisja wskazuje na szczególną rolę niektórych organów Rady Europy, jak Komisji Weneckiej czy GRECO (Grupa Państw Przeciwko Korupcji); Komisja odnotowała też prace nad ponowną próbą przystąpienia Unii Europejskiej do europejskiej Konwencji o ochronie praw człowieka i podstawowych wolności); f) innych instytucji międzynarodowych (jak OBWE czy OECD, ale także Banku Światowego, niektórych biur ONZ).

W odniesieniu do filaru drugiego praworządności, tj. prewencji, Komisja wskazała, że chodzi o mechanizm poprzedzający uruchomienie procedur z art. 7 TUE. Komisja uznała, że obejmuje on „ukierunkowane monitorowanie”, które opierałoby się na cyklicznym przeglądzie praworządności. W związku z tym Komisja przyjęła, że taki przegląd powinien obejmować wszelkie elementy praworządności. Niemniej wskazała, że w grę wchodzą m.in.: systemowe problemy zwiąane z procesem prawodawczym, brak skutecznej ochrony sadowej przez niezależne i bezstronne sady lub nieprzestrzeganie zasady podziału władzy, a ponadto zdolność państw członkowskich do zwalczania korupcji, a także - w zakresie zwiazanym ze stosowaniem prawa UE - zastrzeżenia co do pluralizmu mediów i procesu wyborczego. W szczególności monitoringiem objęto by: zdolności wszystkich podmiotów zaangażowanych $w$ ten proces - sądów, prokuratur, organów ścigania, organów niezależnych, organów administracji publicznej sprawujacych funkcje nadzorcze, rzeczników praw obywatelskich oraz instytucji i osób zajmujaccych się obrona praw człowieka - do wykonywania swoich obowiązków (s. 10). Procesem monitorowania miałyby być objęte wszystkie państwa członkowskie, aczkolwiek 
byłby on bardziej intensywny $w$ tych państwach, $w$ których stwierdzono ryzyko pogorszenia sytuacji lub szczególne problemy (s. 11). Komisja podała też, że informacje o stanie praworządności czerpałaby z wszelkich źródeł, także zewnętrznych wobec Unii Europejskiej, a ponadto zwróciłaby się do państw członkowskich o: większe angażowanie się w wymiane informacji i dialog na temat kwestii zwiazanych $z$ praworządnościa, takich jak reforma sadownictwa, zwalczanie korupcji i proces prawodawczy, lub w sprawie środków wspierających społeczeństwo obywatelskie i niezależne media jako podmioty ksztattujące praworząność [w istocie, byłoby to - jej zdaniem - poszerzenie już podejmowanych działań w tym zakresie].

W nawiązaniu do tego Komisja zaproponowała ustanowienie sieci krajowych punktów kontaktowych w państwach członkowskich: $w$ celu prowadzenia dialogu na temat zagadnień związanych $z$ praworządnością. Sieć ta wykorzystywałaby - i mogłaby włączyć do tego procesu - istniejące już kontakty $w$ dziedzinach zwiazanych z praworządnościa, takich jak sieci krajowych punktów kontaktowych $w$ dziedzinie wymiaru sprawiedliwości i przeciwdziałania korupcji. Stanowiłaby forum do dyskusji na temat kwestii horyzontalnych, w tym, w stosownych przypadkach, ewentualnego rozwoju unijnego zestawu instrumentów $w$ zakresie praworządności, a także wymiany informacji i najlepszych praktyk. Osoby kontaktowe będą koordynować dwustronny dialog z poszczególnymi państwami członkowskimi i pomagać w gromadzeniu i opracowaniu istotnych informacji na potrzeby sprawozdania na temat praworządności [...]. Sieć krajowych punktów kontaktowych mogłaby stanowić forum wczesnego ostrzegania na temat reform związanych $z$ praworządnością oraz dyskusji między państwami członkowskimi (s. 11-12).

Innym instrumentem prewencyjnym miałoby być coroczne sprawozdanie Komisji Europejskiej na temat praworządności. Byłby to dokument syntetyzujący sytuację dotyczącą praworządności w poszczególnych państwach członkowskich, obejmujący także orzecznictwo Trybunału Sprawiedliwości Unii Europejskiej i inne ważne informacje, łącznie z fragmentami tablicy wyników wymiaru sprawiedliwości (zawierającej porównawcze dane o niezależności sądów i ich efektywności krajowej).

Narzędziem prewencyjnym miałby pozostać dialog międzyinstytucjonalny na temat praworządności (między instytucjami Unii Europejskiej), z wykorzystaniem np. rocznego raportu Komisji Europejskiej czy wkładów ze strony Komitetu Gospodarczego i Społecznego oraz Komitetu Regionów. Komisja zapowiedziała też gotowość pogłębienia współpracy z Parlamentem Europejskim, Radą i państwami członkowskimi w sferze m.in. zwiększenia znajomości systemów krajowych. Ponadto Komisja wzywa europejskie partie polityczne do zadbania o to, aby partie krajowe będące ich członkami należycie przestrzegały zasad praworzadności i włączaly tę sprawę w swoje programy ogólnopolityczne ${ }^{6}$.

6 Komisja odwołała się w tym względzie także do rozporządzenia Parlamentu Europejskiego i Rady (UE, Euratom) 2019/493 z 25 marca 2019 r. zmieniającego rozporządze- 
Ostatni filar ochrony praworządności w Unii Europejskiej został powiązany $\mathrm{z}$ reagowaniem na problemy z nią związane w sytuacji, gdy zawiodły mechanizmy krajowe. Komisja zastrzega, że w tej materii zamierza działać z wykorzystaniem orzecznictwa Trybunału Sprawiedliwości, i wyraża przekonanie, że będzie zdecydowana kierować skargi na zarzucane naruszenia do Trybunału, występując $\mathrm{w}$ razie potrzeby o rozpatrzenie sprawy w trybie przyspieszonym oraz o zastosowanie środków tymczasowych (podkreśla generalnie znaczenie czasu: instytucje UE mają działać szybko, w sposób bardziej spójny i skoordynowany, na podstawie ram na rzecz praworządności ${ }^{7}$ ). Komisja ma też tworzyć zestawienia dotyczące ustaleń Trybunału.

W stosunku do art. 7 TUE Komisja odnotowała z zadowoleniem zamiar Rady opracowania nowej procedury przesłuchań w sprawie poszanowania praworządności, zachęcając do jej usprawnienia przez upoważnienie grupy roboczej Rady do przygotowania dyskusji na forum tej instytucji na poziomie technicznym. Komisja też uważa, że Parlament Europejski powinien mieć prawo przedstawienia argumentów w ramach wszczętych postępowań, a nawet widzi możliwość udziału organów Rady Europy lub merytorycznego wkładu innych podmiotów (s. 15-16). Komisja zapowiada również rozważenie sposobu zapewnienia większego zaangażowania innych instytucji na wczesnym etapie procedowania w trakcie działań na rzecz praworządności. Za kluczowe uważa dostarczenie decydentom odpowiedniej wiedzy specjalistycznej, przy zachowaniu autonomii Komisji i jej ocen. Komisja podkreśla, że celem jest szybka deeskalacja sytuacji lub przerwanie formalnej procedury dotyczącej praworządności, jak tylko państwo członkowskie podejmie niezbędne działania.

Komisja zwraca też uwagę na potrzebę konkretnych działań w poszczególnych dziedzinach działania Unii Europejskiej. Ma tu na uwadze m.in. powiązanie budżetu Unii Europejskiej i uogólnionych braków w zakresie praworządności w państwach członkowskich ${ }^{8}$, zwracając uwagę, że już obecnie istnieją mechanizmy o ograniczonym zakresie działania.

nie (UE, Euratom) nr 1141/2014 w odniesieniu do procedury weryfikacji dotyczącej naruszeń przepisów o ochronie danych osobowych w kontekście wyborów do Parlamentu Europejskiego, Dz.Urz. UE L 85, s. 7, które miałoby stanowić podstawę do wykreślenia europejskiej partii politycznej lub fundacji politycznej, która nie przestrzega praworządności z rejestru takich partii/fundacji przez Urząd ds. Europejskich Partii Politycznych i Europejskich Fundacji Politycznych.

7 Komisja podniosła, że w wyroku z 17 grudnia 2018 r., sprawa C-619/18R, Trybunał uznał, że ramy praworządności stanowią pełnoprawny instrument należący do porządku prawnego Unii i wywołujący skutki prawne. Nie jest to wszakże wyrok, lecz postanowienie (ECLI:EU:C:2018:1021). Jednak nie stwierdzam, aby teza Komisji dotycząca charakteru prawnego komunikatu dotyczącego ram została $\mathrm{w}$ tym postanowieniu przesądzona.

8 Projekt rozporządzenia Parlamentu Europejskiego i Rady w sprawie ochrony budżetu Unii w przypadku uogólnionych braków w zakresie praworządności w państwach 


\section{- Geneza dokumentu UE}

Komunikat z lipca 2019 r. jest dokumentem będącym potwierdzeniem kontynuowania działań Komisji Europejskiej w sferze promocji praworządności oraz zapobiegania jej naruszeniom i reagowania na nie. $\mathrm{W}$ ujęciu formalnym stanowi bezpośrednie następstwo wcześniej wydanego (dnia 4 kwietnia 2019 r.) Komunikatu skierowanego do Parlamentu Europejskiego, Rady Europejskiej i Rady pt. Dalsze umacnianie praworzadności w Unii - aktualna sytuacja i możliwe kolejne działania ${ }^{9}$, w którym Komisja, jak sama zauważa, przedstawiła przegląd obecnego zestawu narzędzi służących rozwiązywaniu problemów w zakresie praworządności $w$ Unii $i$ otworzyła debate nad udoskonaleniem tych narzędzi. Zdaniem Komisji debata zainicjowana komunikatem z kwietnia 2014 r. wykazała wagę praworządności i rosnącą obawę o zachowanie jej standardów, a także potrzebę wzmocnienia narzędzi Unii Europejskiej służących jej do utrzymania praworządności. Komisja stwierdziła też, że idea umocnienia praworządności spotkała się z pozytywnym odbiorem państw członkowskich (szczyt w Sybinie w maju 2019 r.) oraz najważniejszych organów Unii Europejskiej (Rada Europejska, „Nowy program strategiczny na lata 2019-2024"10, debatach odbywanych w Parlamencie Europejskim w lata 2014-2019, programach prezydencji Rady), a także europejskich partii politycznych.

\section{- Informacja o stanie prawa obowiązującego w Polsce w materii objętej treścią dokumentu UE}

Komunikat z lipca 2019 r. dotyczy bardzo szerokiego spektrum zagadnień. W gruncie rzeczy dotyczy on ustroju państwa, a zatem rozwiązań ujętych w Konstytucji RP, a także ustawodawstwie ustrojowym. Ponadto dotyczy tych dziedzin

członkowskich, $\operatorname{COM}(2018) 324$ final. Jego podstawą prawną miałby być art. 322 ust. 1 lit. a TFUE, a zatem akt byłby przyjęty w ramach zwykłej procedury prawodawczej, tj. większością kwalifikowaną głosów.

$9 \operatorname{COM}(2019) 163$ final. Omawiany Komunikat jest jednak również z pewnością konsekwencją wcześniejszego Komunikatu do Parlamentu Europejskiego i Rady z 11 marca 2014 r. pt. Nowe ramy UE na rzecz umocnienia praworządności (COM(2014)158 final).

10 Tekst dostępny na stronie: https://www.consilium.europa.eu/media/39919/a-new-strategic-agenda-2019-2024-pl.pdf. Rada Europejska stwierdziła w nim m.in.: Europa musi być miejscem, w którym ludzie czuja się wolni i bezpieczni. UE musi bronić podstawowych praw i swobód przystugujących jej obywatelom zgodnie z traktatami oraz chronić ich przed istniejącymi i pojawiajacymi się zagrożeniami. Wspólne wartości leżące u podstaw naszych modeli demokratyczno-społecznych sa fundamentem wolności, bezpieczeństwa i dobrobytu w Europie. Praworzadność, która odgrywa zasadnicza rolę we wszystkich naszych demokracjach, jest kluczową gwarancją, że wartości te sa dobrze chronione; musi być w pełni przestrzegana przez wszystkie państwa członkowskie i przez UE. 
prawa, w których zasada praworządności ma szczególne zastosowanie, jak w tzw. działach prawa sądowego, a nawet szerzej - wszędzie tam, gdzie wchodzi w grę z jednej strony działanie organów państwa na podstawie i według obowiązującego prawa, a $\mathrm{z}$ drugiej, gdzie znaczenie ma sądowa, a nawet administracyjna ochrona praw jednostki.

\section{Ocena dokumentu UE}

\section{- Ocena społecznych, gospodarczych i finansowych skutków dokumentu UE}

Komunikat z lipca 2019 r. nie generuje bezpośrednich skutków społecznych, gospodarczych i finansowych. Dopiero wprowadzanie w życie niektórych rozwiązań może rodzić następstwa społeczne (wizerunkowe i nie tylko) oraz finansowe (wynikające ze zmian ustawowych i organizacyjnych w razie stwierdzenia niezgodności z zasadą praworządności przyjętych lub obowiązujących rozwiazań krajowych przez Trybunał Sprawiedliwości UE).

\section{- Ocena zgodności działań UE, o których mowa w dokumencie UE, z zasadą pomocniczości}

Dokument nie jest projektem aktu prawnego. Nie dotyczy go zasada pomocniczości.

\section{- Ustosunkowanie się do informacji Rady Ministrów na temat omawianego dokumentu UE}

Komitet ds. Europejskich Rady Ministrów przyjął stanowisko w sprawie komunikatu z lipca 2019 r. dnia 1 października 2019 r. W dokumencie tym Komitet ds. Europejskich wyraził:

1) poparcie dla tych propozycji KE, które maja bezpośrednie umocowanie $\boldsymbol{w}$ Traktatach [podkreślenie w oryginale] - szanuja istniejace obszary kompetencji, maja charakter obiektywny i niedyskryminujacy, a przy tym nie dubluja istniejacych już procedur,

2) poparcie dla wypracowania standardów przestrzegania i ochrony praworządności, które miałyby takie samo zastosowanie do wszystkich państw członkowskich (sprzeciw wobec podwójnych standardów traktowania, nacisk na zasadę równości państw), aczkolwiek przy jednoczesnym uwzględnieniu różnic ustrojowych, zakorzenionych $w$ narodowych konstytucjach (zgodnie z art. 4 ust. 3 TUE),

3) warunkowe poparcie dla cyklicznego przeglądu praworządności (może spetnić swoja role jedynie pod warunkiem, że będzie opierać się na zasadach obiektywizmu, niedyskryminacji $i$ równego traktowania wszystkich państw członkowskich UE; zwrócono uwagę na konieczność zapewnienia odpowiedniego udziału państw członkowskich $w$ procesie powstawania i realizowania przegladu, a także opierać się na zasadzie równej intensywności i wnikliwości w stosunku 
do każdego państwa członkowskiego (usunięcie marginesu swobody działania Komisji Europejskiej),

4) sprzeciw wobec określenia zakresu cyklicznego przeglądu, który zdaniem Rady Ministrów wykracza poza ramy na rzecz praworządności ustalone w komunikacie z kwietnia 2019 r. (zdolność państw członkowskich do zwalczania korupcji, zastrzeżenia do pluralizmu mediów i procesu wyborczego; istnienie pozostalych elementów, których monitorowania chciałaby dokonywać KE nie stanowi przedmiotu zobowiązań nałożonych na państwa członkowskie $w$ traktatach, co zgodnie z zasada kompetencji przyznanych oznacza, że odpowiedzialność za ich zapewnienie spoczywa na państwach członkowskich $i$ ich instytucjach krajowych; szeroki zakres przeglądu może prowadzić do rozmycia celu mechanizmu i dublowania instrumentów oraz powstania ryzyka używania mechanizmu do doraźnych celów politycznych; stwierdza się też: Zakres przeglądu powinien zostać ograniczony do funkcjonowania systemów wymiaru sprawiedliwości $w$ procesie stosowania prawa UE. Informacje wykorzystywane przy ocenie przestrzegania przez państwa członkowskie praworządności powinny pochodzić z oficjalnych i sprawdzonych źródet, mieć rzetelny charakter oraz koncentrować się bezpośrednio i jednoznacznie na zakładanym w Komunikacie celu ochrony praworzadności),

5) co do zasady popiera ustanowienie punktów kontaktowych (właściwe byłoby Ministerstwo Sprawiedliwości w ścisłej współpracy z Ministerstwem Spraw Zagranicznych),

6) sprzeciw wobec wprowadzenia mechanizmu warunkowania przyznania państwom członkowskim określonych uprawnień $w$ ramach polityk sektorowych UE przestrzeganiem przez nie szeroko rozumianej zasady praworządności - na wzór obecnie negocjowanego rozporzadzenia o ochronie budżetu UE w przypadkach stwierdzonych w państwach członkowskich "uogólnionych braków" $w$ zakresie praworząności; uznaje się, że mechanizm taki ma wątpliwą wartość wobec istnienia procedur z art. 7 TUE, art. 258 TFUE (szczególnie negatywnie oceniane są tzw. uogólnione braki praworządności, które to określenie dawałoby Komisji zbyt dużą swobodę ferowania ocen i zagrażałoby pewności prawa),

7) sprzeciw wobec przyznania Komisji dodatkowej roli $w$ procesie deeskalacji lub wychodzenia państw czlonkowskich $z$ procedury $z$ art. 7 TUE. Traktat o Unii Europejskiej nie przewiduje żadnej roli dla Komisji Europejskiej na tym etapie procedury. Jej wprowadzenie wykraczałoby poza ramy traktatowe i naruszałoby równowage instytucjonalna, a zwłaszcza kompetencje Rady w zakresie oceny spetniania przez państwo członkowskie wartości, o których mowa w art. 2 TUE.

Oceniając stanowisko rządowe, należy zwrócić uwagę na cztery niepodważalne ustalenia. Po pierwsze, zgodnie $\mathrm{z}$ art. 2 TUE, rządy prawa (praworządność) stanowią jedną z wartości, na których opiera się Unia Europejska. Wartość ta uznana została za wspólną dla państw członkowskich. Nie została ona jednak jednoznacznie sformułowana na poziomie prawa pierwotnego (inaczej niż np. prawa podstawowe), podobnie, jak np. demokracja. Po drugie, rządy prawa pod- 
legają ochronie w Unii Europejskiej w kontekście kontroli prewencyjnej, o której mowa w art. 49 TUE (przystąpienie do Unii - kontrola państwa kandydującego), a także represyjnej (art. 7 TUE w związku z art. 354 TFUE). Po trzecie, Komisja Europejska odgrywa pewną rolę zarówno w procedurze prewencyjnej (art. 49 zdanie trzecie 3 TUE), jak i represyjnej (art. 7 ust. 1 i 2 TUE). Niemniej w żadnej $\mathrm{z}$ nich nie przyznano jej kompetencji o charakterze władczym w stosunku do państw członkowskich. Ma ona natomiast kompetencję opiniującą (prewencja) lub inicjującą (represja). W ramach tej ostatniej i na potrzeby właściwej procedury $\mathrm{z}$ art. 7 ust. 1 lub ust. 2 TUE Komisja może dokonywać własnych ocen sytuacji (ocen wewnętrznych), lecz ich adresatem nie jest państwo członkowskie, lecz właściwe organy decyzyjne (Rada Unii Europejskiej bądź Rada Europejska, czyli organy międzyrządowe, działające w specjalnym trybie). Po czwarte, ani Unia Europejska nie jest organizacją o kompetencji domniemanej (art. 4, 5 TUE), ani Komisja Europejska nie jest organem o kompetencji ogólnej (art. 17 TUE). W ostatnim przypadku nie wolno tego mylić z kompetencją do wspierania interesu ogólnego Unii, a nawet z przypisaną jej funkcją strażnika traktatów, gdyż Komisja, podobnie, jak inne instytucje i organy Unii, muszą działać na podstawie i w granicach kompetencji im przyznanych w traktatach (art. 13 ust. 2 TUE). Oznacza to, że Komisja może działać legalnie jedynie w granicach kompetencji Unii i, bardziej konkretnie, kompetencji jej przyznanych. Nie może ich uogólniać czy poszerzać. Jej kompetencje muszą mieścić się w granicach kompetencji wyraźnych lub dorozumianych (nie wypowiedzianych wprost, ale mieszczących się w ramach traktatowych; przy tym cele i zadania to nie to samo, co kompetencje). Normy kompetencyjne nie podlegają wykładni rozszerzającej, co dotyczy tak Unii Europejskiej, jak i Komisji Europejskiej. Wynika z tego, że Komisja Europejska nie ma kompetencji do ustalenia treści zasady praworządności, a Trybunał może to zrobić jedynie w granicach wykładni traktatów (w granicach kompetencji Unii). Nie ma tu miejsca na ustalanie treści wartości czy tworzenie procedur pozatraktatowych, wykraczających poza umocowania ujęte w prawie pierwotnym. Kompetencja ta jest zarezerwowana dla państw członkowskich (art. 4 ust. 1 TUE). Aktywność Komisji nie może niejako „naprawiać” stwierdzonych słabości lub braków traktatów (zob. stosowane procedury rewizyjne z art. 48 TUE; z postanowienia tego wynika, że Komisja może zaproponować zdefiniowanie praworządności, lecz to państwa członkowskie są decydentami w sprawie). Nawet najszlachetniejszy cel nie może uświęcać środków. Przy ocenie komunikatu z lipca 2019 r. na wykraczanie przez Komisję poza istniejące podstawy traktatowe nie pierwszy raz zwracała również uwagę Służba Prawna Rady Unii Europejskiej ${ }^{11}$.

Z podanych względów wstrzemięźliwie należy podchodzić do miękkich zmian proponowanych przez Komisję, jak np. przeglądu cyklicznego, ponieważ w ten sposób ustanawia się procedurę pozatraktatową oceny państwa członkow-

11 Opinia Służb Prawnych Rady z 27 maja 2014 r., nr 10296/14. 
skiego (podobnie negatywnie ze względów prawnych należy ocenić procedury wprowadzane $\mathrm{w}$ trakcie działań na rzecz praworządności na mocy komunikatu z 2014 r., który wbrew sugestii Komisji nie jest elementem prawa Unii Europejskiej), co prawda politycznej, lecz nieprzewidzianej traktatami. Przy tym nieuzasadnione jest szerokie ujęcie zakresu przeglądu (nabierające cechy ogólnej, wszechogarniającej oceny ustrojowej państwa z naruszeniem zasady z art. 4 ust. 2 TUE, tj. zasady poszanowania tożsamości państwa nierozerwalnie związanej z podstawowymi strukturami konstytucyjnymi i politycznymi), mieszające $\mathrm{w}$ istocie zasadę rządów prawa z zasadą demokracji, bez odpowiedniego umocowania traktatowego. Stosowny mechanizm przeglądowy miałby uzasadnienie, gdyby znalazł podstawę $\mathrm{w}$ traktatach i łączyłby się z określeniem stosownej procedury, a zwłaszcza katalogu standardów, jakie państwa członkowskie uważają za definiujące praworządność (być może nie tylko, ale np. również demokrację), tj. tak, jak w przynajmniej niektórych innych organizacjach integracji regionalnej (Ameryki Łacińskiej czy nawet Afryki). Wówczas także możliwe byłoby nadanie realnego kształtu procedurom $\mathrm{z}$ art. 7 TUE.

Za nieuzasadnione można też uznać swobodne przenoszenie przez Komisję standardów ustalanych w innym kręgu państw na poziom unijny i ich egzekwowanie tak, jakby stanowiły element prawa Unii Europejskiej. Dotyczy to także Rady Europy. Wskazywanie umowy z tą organizacją (jest to memorandum of understanding, $\mathrm{z}$ reguły umowa o charakterze politycznym, a nie prawnym - taki też wniosek nasuwa się z lektury memorandum z 2007 r.) jako podstawy takiego działania stanowi nadużycie. Czym innym jest bowiem współpraca między organizacjami, a czym innym bezpośrednie wykorzystywanie standardów przyjętych $\mathrm{w}$ jednej z nich $\mathrm{w}$ drugiej. W sferze praworządności memorandum wyraża jedynie wolę współpracy i dążenia do ustalenia wspólnych standardów w sferze praworządności (pkt 23-26) ${ }^{12}$.

Mniej sceptycznie można podejść do ustanawiania punktów kontaktowych. Niemniej w obecnym stanie prawnym pomysł ten może być wykonany w świetle zasady lojalnej współpracy (art. 4 ust. 3 TUE) jedynie w odniesieniu do kontroli praworządności w związku z poszczególnymi dziedzinami integracji, a nie generalnie w odniesieniu do kontroli praworządności.

Wbrew pozorom mniej oczywista jest niedopuszczalność łączenia praworządności z działaniem w różnych sektorach aktywności Unii Europejskiej. Jako zasada wspólna Unii może bowiem przenikać różne kompetencje regulacyjne Unii, w tym kompetencje budżetowe. Jednak znowu powstaje problem jej rozumienia. W szczególności bowiem koncepcja uogólnionego braku w zakresie praworządności przyjęta w projekcie unijnego rozporządzenia w sprawie ochrony budżetu Unii w przypadku uogólnionych braków w zakresie praworządności

12 Tekst memorandum: https://rm.coe.int/CoERMPublicCommonSearchServices/Disp layDCTMContent?documentId=090000168045bc99. 
w państwach członkowskich (oznaczająca szeroko rozpowszechniona lub powtarzająca się praktykę lub zaniechanie organów publicznych albo stosowany przez nie środek, które naruszają praworządność) w powiązaniu z ogólnikową definicją praworządności (bezpodstawnie konstruowaną na poziomie prawa pochodnego; koncepcja praworządności odnosi się do wartości Unii wpisanych do art. 2 TUE, do których należą: zasada legalizmu, oznaczajaca przejrzysty, rozliczalny, demokratyczny i pluralistyczny proces przyjmowania aktów prawnych; pewność prawa; zakaz arbitralności $w$ działaniu władz wykonawczych; skuteczna ochrona sądowa, $w$ tym ochrona praw podstawowych, dokonywana przez niezależne sady; podziat władzy i równość wobec prawa) oraz w związku z przewidywaną procedurą działania rodzą poważne wątpliwości co do możliwości praworządnego stosowania rozporządzenia (zob. art. 2 i 5 projektowanego rozporządzenia).

\section{Opinia prawna}

\section{Podstawa prawna dokumentu UE}

Komunikat Komisji nie jest projektem aktu prawnego UE. Nie wymaga wskazania podstawy prawnej. Można wszakże przyjąć, że jest to art. 17 ust. 1 TUE dotyczący ogólnie Komisji Europejskiej i jej kompetencji. Jako dokument niebędący również projektem aktu ustawodawczego UE, nie podlega ocenie co do zgodności z zasadą pomocniczości na podstawie protokołu nr $2 \mathrm{w}$ sprawie stosowania zasad pomocniczości i proporcjonalności. Komunikat dotyczy zagadnień ogólnych, związanych z dalszym funkcjonowaniem Unii Europejskiej i jej perspektywami rozwojowymi. Zgodnie $\mathrm{z}$ art. 1 protokołu nr 1 podlega natomiast konsultacjom z parlamentami narodowymi.

Wobec tego brak jest przesłanek, które uniemożliwiałyby Komisji wydanie komunikatu w omawianej kwestii.

\section{Skutki prawne}

Opublikowanie komunikatu nie wywołuje bezpośrednich skutków prawnych w sferze prawa Unii Europejskiej i prawa polskiego.

Zawarte w komunikacie propozycje nie będą wymagały podjęcia konkretnych działań prawnych. Dopiero konkretyzacja mechanizmów prawnych może rodzić konieczność przyjmowania konkretnych działań prawnych.

\section{Kwestie proceduralne}

\section{- Procedura przyjmowania dokumentu UE}

Komisja przyjęła analizowany komunikat 17 lipca 2019 r. Przyjęcie komunikatu nie jest związane z zachowaniem określonej, wynikającej z prawa traktatowego, procedury. 


\section{- Działania Komisji do Spraw Unii Europejskiej}

Dnia 27 sierpnia 2019 r. Komisja do Spraw Unii Europejskiej zwróciła się do Rady Ministrów o przedstawienie informacji w sprawie komunikatu na podstawie art. 3 ust. 2 ustawy z 8 października 2010 r. o współpracy Rady Ministrów z Sejmem i Senatem w sprawach związanych z członkostwem Rzeczypospolitej Polskiej w Unii Europejskiej (Dz.U. nr 213, poz. 1395). Dnia 1 października Komitet ds. Europejskich Rady Ministrów przyjął stanowisko w sprawie komunikatu z lipca 2019 r. Komisja może rozpatrzyć dokument w trybie art. 151 ust. 1 regulaminu Sejmu. Komisja nie jest ograniczona terminami, poza tymi, które mogą wynikać z celowości podejmowanych przez nią działań.

\section{Wniosek}

Opiniowany komunikat Komisji Europejskiej z lipca 2019 r. jest wyrazem kontynuacji działań Komisji podejmowanych w sferze praworządności zwłaszcza od 2014 r. Krytyczna ocena tych działan dotyczy braku odpowiednich podstaw prawnych dla tej aktywności. 